\title{
ADVANCING LARGER DEMOCRACY IN INDONESIA THROUGH ISLAMIC PRINT MEDIA
}

\author{
Akh. Muzakki ${ }^{1}$ \\ State Institute for Islamic Studies (IAIN) Sunan Ampel, Surabaya, Indonesia
}

\section{Abstract}

Over the past one decade, Indonesia has been renowned for its achievement in consolidating and establishing democracy after having experienced thirty two year political authoritarianism. The power is now step by step leased back to the people. In the least form, people are little by little getting access to the processes of policy-making. Their aspirations, instead of being undermined, are considered to be as gradually important as those of political elites. This paper is an attempt to examine the role of print media in enhancing the democratisation processes through the analysis of the production of Islamic ideas within print media publication. For the purpose of simplification, print media publication can be regarded as part of the essential translation of the press, a pillar of democracy. As a focus of analysis, this paper deals with print publications, in the form of both Islamic books and magazines, produced by Muslim scholars or activists in Indonesia. Islamic books are presented by those produced by publishers, such as Mizan, Gema Insani Press, and Wibdah Press. Islamic magazines are presented by Sabili, Hidayah, and Jihadmagz:

[Lebih dari satu dekade terakhir, Indonesia dikenal sebagai negara yang berhasil melakukan konsolidasi demokrasi setelah mengalami tiga puluh dua tahun otoritarianisme Orde Baru. Kekuatan politik secara perlahan dikembalikan ke rakyat. Setidaknya, rakyat sedikit demi sedikit semakin memiliki akses atas pembuatan kebijakan. Aspirasi mereka kemudian

${ }^{1}$ I wish to thank both Prof. Robert E. Elson and Prof. Peter Spearritt from The University of Queensland for their comments on parts of the earlier draft of this paper. 
diperbitungkan dan dianggap penting seperti aspirasi elit politik. Artikel ini mendiskusikan peran media-cetak dalam proses demokratisasi, yaitu dengan mengalisis produksi gagasan-gagasan tentang Islam yang dimuat dalam media cetak. Secara umum, media cetak merupakan salah satu bentuk, pers yang menjadi salah satu pilar demokrasi. Pembahasan dalam artikel ini difokuskan pada buku dan majalah yang diterbitkean oleh ulama atau aktifis di Indonesia. Mizan, Gema Insani Press, dan Wibdah mewakili penerbit buku, sementara Sabili, Hidayah dan Jihadmagr. mewakili kelompok majalah.]

Keywords: authority, Islamic publication, print media, democratisation

\section{A. Introduction}

Over the past decade, Indonesia has been renown for its achievement in consolidating and establishing democracy after experiencing thirty two years of political authoritarianism. Three general elections conducted after the toppling of Soeharto from power in 1999, 2004 and 2009 have shown that democracy has flourished in an increasingly well-established way. Step by step power is leased back to the people. In the smallest form, people's access to the processes of policy-making is increasing. Their aspirations, instead of being undermined, are considered to be as important as those of political elites.

Five pillars are needed to support the establishment of a sustainable democracy; the legislature, executive, judiciary, free press, and civil society. The improvement of the quality of democracy revolves around strategies for enhancing the capacity of these pillars. For Indonesia, new democratic strategies exploited by so-called "Scandinavian proposals" deserve thorough attention in an attempt to advance larger democracy. The term "Scandinavian proposals" in this context means, as David Held asserts, that "state institutions of social policy can be transformed into more responsive, effective and democratic units if control of them is reclaimed or leased back to the people who use and service them."2

Much has been written about the consolidation and institutionalisation of democratic practices through political institutions, but less emphasis has been put to examining the particular role of print media in producing and consuming ideas leading to the advancement of larger democracy

\footnotetext{
${ }^{2}$ David Held, Models of Democracy (Cambridge: Polity Press, 1987), p. 288.
} 
in Indonesia. Scholars such as Tim Meisbuger, ${ }^{3}$ Bob S. Hadiwinata and Christoph Schuck, ${ }^{4}$ David Bourchier and John Legge, ${ }^{5}$ and Richard Mann ${ }^{6}$ put emphasis on the consolidation and institutionalisation practices of democracy through political institutions, although they do not deal exclusively, or at least sufficiently, with the nurturing practices of democratic values by means of print media. Advancing larger democracy through the democratisation of Islamic ideas developed within Islamic books and magazines is, therefore, a neglected subject of research.

Meanwhile, media itself, particularly of the print variety, has a highly significant role in struggles for power and 'meaning-making', as elaborated below. The Indonesian experience during the New Order period (1966-1998) sent an important lesson that the media was perceived by the ruling powers as having to be tightly controlled since it would otherwise lead to the rise of political disobedience by the people against the regime. During the period of Soeharto's power, open debate on many Islamic issues was difficult due to the censorship and repression of the New Order regime. ${ }^{7}$ When this control ended however, open debate on many Islamic issues appeared for public consumption. This is the reason that varied Islamic ideologies, ranging from traditionalist, modernist, reformist to even jihadits Islam has come to the forefront again.

This paper is an attempt to examine the role of print media in enhancing the democratisation processes through the analysis of the production of Islamic ideas within print media publication. For the purpose of simplification, print media publication can be regarded as part of the essential element of the press, a pillar of democracy. As a focus of analysis, this paper deals with print publications, in the form of both Islamic books and magazines, produced by Muslim scholars or activists in Indonesia. Islamic books are presented by those produced

${ }^{3}$ Tim Meisbuger, Democracy in Indonesia: A Survey of the Indonesian Electorate in 2003 (Jakarta: The Asia Foundation, 2003).

${ }^{4}$ Bob S. Hadiwinata and Christoph Schuck (eds.), Democracy in Indonesia: The Challenge of Consolidation (Baden-Baden: Nomos, 2007).

${ }^{5}$ David Bourchier and John Legge (eds.), Democracy in Indonesia, 1950s and 1990s (Clayton, Victoria: Centre of Southeast Asian Studies, Monash University, 1994).

${ }^{6}$ Richard Mann, Fight for Democracy in Indonesia (Canada: Gateway, 1999).

${ }^{7}$ See Julie Chernov Hwang, "Does Participation Matter? Effective Authoritarianism in New Order Indonesia," in Peaceful Islamist Mobilization in the Muslim World: What Went Right (New York: Palgrave Macmillan, 2009), pp. 47-74. 
by publishers, such as Mizan (based in Bandung), Gema Insani Press (GIP, based in Jakarta), and Wihdah Press (based in Yogyakarta). Islamic magazines are represented by Sabili (based in Jakarta), Hidayah (based in Jakarta), and Jihadmagz (based in Jakarta).

The paper argues that democratisation of Islamic ideas contributes to the advancing of larger democracy in Indonesia. It further argues that the production of ideas through Islamic books and magazines becomes a foundation for the democratisation of ideas. In the first part, the paper deals with the theoretical framework of the role of media in struggling for power and meaning-making. In what follows, it examines the impact of this access to new ideas on the personal autonomy of Muslim individuals and intellectual authority connected to religious institutions. The rest of the paper focuses on the rationalisation of thinking through print media and the politics of authority, along with its role in advancing larger democracy in Indonesia.

\section{B. Media: Struggling for Power and Struggling for Meaning}

Scholars of media and communication studies have come to the agreement of the essential role of media in changing individual's minds. Terry Flew argues that media have a considerably huge effect on an individual's life. The effect is arguably so present that an individual thinks and probably further acts in accordance with the information gained through the media. As Flew asserts, "the media influences not only what we think but [also] how we think." 8 Marshall McLuhan asserts that "the medium is the message" itself. As the message, the media affects the worldview of the receiver. ${ }^{9}$ Harold Innis maintains that such an effect of media results from the capacity of the media in sustaining the message by which its transportability over space and its durability over time are maintained.

Meaning is, therefore, a key component behind media production. Both media and meaning can be illustrated as two sides of the same coin. As P. Eric Louw argues, "In the contemporary world, meanings

${ }^{8}$ Terry Flew, New Media: An Introduction (Melbourne; London: Oxford University Press, 2005), p. 30.

${ }^{9}$ Marshall McLuhan, The Medium is the Massage: An Inventory of Effects (New York: Random House, 1967). 
are frequently made within institutions called the media where meaning production has become professionalized." ${ }^{10}$ So, what individuals think about and how they think are closely connected to the production of meaning through media. Louw further says, "Such media-ized meaningmaking is necessarily associated with sets of relationships between people that have been turned into institutionalized behaviours and work practices."11

Through the production-consumption mechanism, media publication gives rise to power relationship among individuals within community, and between people and the state. The media has recently become the main concern of people. Attempts to enhance their public profiles need to be undertaken through media. Almost all Muslims groups have their own publication media, in the form of books and magazines. It is for this reason that the Islamic publication industry is booming.

The Islamic publication industry is not limited to printed materials only. There is a wide range of products to be found on the market in ever growing quantities. Apart from books, journals, magazines, pamphlets, and newspapers, they also include audio and video cassettes as well as CDs, VCDs, and DVDs. These varied products have flooded the market in such a stunning way that Islamic publication needs to be perceived as having deeply coloured the Indonesian public domain.

Islamic books and magazines play the largest role in the Islamic publication industry. This is not only because they are being produced in ever increasing numbers, but is also due to the lengthy experience of some of their publishers. Moreover, they are distributed not only through chains of specifically Islamic-oriented bookshops (broadly defined as bookshops which specialise in selling Islamic printing materials) such as Walisongo and Maarif, but also through chains of general bookshops such as Gramedia, Karisma or Gunung Agung, which reserve an extensive amount of shelf space and book displays for Islamic materials.

Islamic books and magazines are not only sold through large national chains such as the five bookshops just mentioned, but also through small local bookshops, and even by street vendor booksellers.

${ }^{10}$ P. Eric Louw, The Media and Cultural Production (London, Thousand Oaks, New Delhi: SAGE Publications, 2001), p. 1.

${ }^{11}$ Louw, The Media and Cultural Production, pp. 1-2. 
Further, they are displayed on trotoar (sidewalks), or on the verandas of mosques, or on the pavement of the streets where mosques are located. They are even displayed and on sale at the entrance of special events such as seminars or conferences. In short, Islamic books and magazines continuously inundate the print media market, both nationally and locally, in modern and traditional types of outlets.

In Indonesia, the Islamic publication industry has presented itself in recent years as a developing business. M.U. Salman, the former executive editor of Sabili, a Jakarta-based popular Islamic magazine, encapsulates this sense of growth as follows:

$\ldots$ is it true that so-called Islamic business could not develop in this country? The rising publication of Islamic books from the early 1990s up to now clearly contradicts this view. [In addition to this,] The booming of nasyid [a breed of Islamic music] cassettes and [other] Islamic songs in recent times [also] represents sufficient factual data to answer such a question. The dominance of Islamic books in every large book fair with a huge number of consumers indicates good prospects for the business of Islamic media. ${ }^{12}$

As with Islamic book publication, the number of Islamic magazines has also increased along with their profitability, both in terms of the number of agencies and products. Less than a year after its first establishment in 2001, sales of the Hidayah magazine had already reached 100,000 per issue. ${ }^{13}$ The saleability of the magazine became even greater over time. In 2004, the commercial turnover of Hidayah reached 350,000 copies per issue, a number other Islamic magazines have not achieved. Sabili has had its share of ups and downs. The period 1988-1991 represented an episode of early development in which the magazine was not routinely and professionally produced. First produced in 1988 in a run of 2,000 copies, there was no publication for another six months. Since 1991, however, the magazine has been managed professionally in an organised and routine way. In 1993 the magazine sold 60,000 copies per issue. In 2000, sales of the magazine reached 135,000 copies per issue. Jihadmagz is an attractively printed Islamic magazine which

${ }^{12}$ See M.U. Salman, "Saatnya Media Islam Tampil," Sabili, no. 10, year XII (3 December 2004), pp. 12-13.

${ }^{13}$ Interview with the editor-in-chief of Hidayah, Ridwan, Depok, 27 March 2008. 
pays special attention to the raising of the issue of jibäd among local communities in Indonesia. It is second to none amongst Islamic magazines specialising in the dissemination of jihadist ideas with its strong accentuation and orientation towards the raising of Muslims' religiousideological awareness of waging physical war against the West and infidels. Production of Jihadmagz is exclusive. The magazine is produced in full colour and hard paper. It sells at Rp. 45,000, a price that is relatively expensive in comparison to other well-established news magazines such as Tempo, which sells for Rp. 22,500. In the market, Jihadmagzperforms quite well as its first issue in March 2008, for example, was printed 5,000 times but, within less than two months, 4,000 copies had already been sold. ${ }^{14}$

In short, people are now provided with huge production of Islamic books and magazines with a wide range of ideologies. Indonesian Islam then cannot be understood except within an understanding of the heterogeneous character of its expressions, both in terms of its socio-political economy and cultural religiosity. The huge production of Islamic books and magazines is evidence of this heterogeneous character. All Muslim groups, in particular, produce these print publications in order to struggle for power and meaning-making in the eyes of Muslim communities. These publications not only affect Muslim readers as their consumers in what they think but also how they think, as suggested earlier, about socio-religious and even political economic matters. Pluralism in Islamic ideas is now at the centre of the public expressions in Islamic print media. Larger democratisation processes eventually start from the democratisation of ideas following the production-consumption mechanism within media publication.

\section{Capitalisation of Ideas: Between Personal Autonomy and Authorities of Religious Institutions}

Intellectual authority has recently become an increasingly stimulating subject of academic discussion not only in media but also religious studies. Scholars such as Robert Wuthnow, Roof, Eileen Barker, and Stewart M. Hoover ${ }^{15}$ have attempted to analyse the increasing

${ }^{14}$ Interview with Jibriel, Bintaro, Tangerang, Banten, 25 April 2008.

${ }^{15}$ Robert Wuthnow, The Restructuring of American Religion: Society and Faith since World War II (Princeton: Princeton University Press, 1988); Wade Clark Roof, Spiritual 
manifestations of what can be commonly referred to as "personal autonomy" in relation to religious and spiritual expressions, mediated particularly within publications. Central to the analysis is the impact of publication media on the manifestation of the intellectual authority of religious scholars.

The increasing manifestations of publication media contributes to the enhancing of personal intellectual authority through the promotion of the ideas an individual works on. This enhancement is even greater when the capitalisation of publication media emerges in a strong way. An interconnected twofold result, moreover, then emerges. On the one hand, the capitalisation of publication media gives rise to the capitalisation of ideas. On the other hand, the capitalisation of ideas leads to the strengthening of the profitable marketisation of publication media. This capitalisation treats ideas as a business commodity to be marketised to consumers. In order to reach as wide an audience as possible, those ideas are mass produced and widely marketed. Technological advances in the print industry add another factor to the increasing capitalisation of ideas and the profit-oriented marketisation of publication media.

In the case of recent developments in Indonesia, as in many other parts of the world, the capitalisation of ideas leading to the commercialisation of publication media, together with the technological advances in print industry, appears high. In relation to the manifestation of intellectual authority, this growing phenomenon has had three results: first, increasing self autonomy and reduced authority of religious institutions such as 'ulama', kyai or ustadr, second, the emergence of a socalled rationalisation of Islamic thinking amongst Indonesian Muslims; and third, the strengthening of a so-called "politics of authority" through the contestation of intellectual influence among Muslim scholars in front of Muslim consumers.

Marketplace: Baby Boomers and the Remaking of American Religion (Princeton, New Jersey: Princeton University Press, 1999); Eileen Barker, "Crossing Boundary: New Challenges to Religious Authority and Control as a Consequence of Access to the Internet," in Morten T. Højsgaard \& Margit Warburg, Religion and Cyberspace (New York: Routledge, 2005), pp. 67-85; Stewart M. Hoover, "Religion, Media and Identity: Theory and Method in Audience Research on Religion and Media," in Jolyon Mitchell and Sophia Marriage (eds.), Mediating Religion: Conversations in Media, Religion and Culture (London; New York: T \& T Clark, 2003), pp. 9-19. 
Increasing self autonomy and reduced authority of religious institutions such as 'ulamä', kyai or ustadz are a logical consequence of the growing production, capitalisation and massive marketisation of Islamic ideas through publications. Central to this self autonomy is the emergence of auto-didacticism as a method of Islamic learning among Muslims, as further explained below. Due to this capitalisation, massive marketisation, and commodification of Islam, some established religious institutions or figures are no longer as influential as in the past, ${ }^{16}$ even though others maintain similar influence. Personal authority has been increasingly strengthened in place of the reduced prerogatives and authorities of religious institutions. As Hoover puts it, "as the self and its quest come more into play, the prerogatives of religious institutions to legitimate certain symbolic forms and practices fade, opening the way for a wider range of symbolic resources to be brought to bear." Among the more significant kinds of symbolic resources are, to borrow the words of Hoover, "the cultural commodities of the media sphere." ${ }^{17}$ In other words, media acts as a producer and transmitter of those cultural commodities, so that it becomes a marketplace where people consume the commodified forms of Islamic ideas.

Media has made people more autonomous in understanding and articulating their religious beliefs. Borrowing the perspective of Wuthnow, ${ }^{18}$ media has contributed to a so-called "restructuring of religious beliefs", reconstructing and remaking religious identity, understanding and expression to be oriented to the "self" rather than "religious institutions" which are outside of the "self". While scholars such as David Morley, Kevin Robins and Rosalind I.J. Hackett ${ }^{19}$ argue that the media has now

${ }^{16}$ Greg Fealy, "Consuming Islam: Commodified Religion and Aspirational Pietism in Contemporary Indonesia," in Greg Fealy and Sally White (eds), Expressing Islam: Religious Life and Politics in Indonesia (Singapore: Institute of Southeast Asian Studies, 2008), p. 16; Barker, “Crossing Boundary," pp. 73-80; Noorhaidi Hasan, Laskar Jihad: Islam, Militancy, and the Quest for Identity in Post-New Order Indonesia (Ithaca: Southeast Asia Program, Cornell University, 2006), pp. 86-87.

${ }^{17}$ Hoover, "Religion, Media and Identity," p. 12.

${ }^{18}$ Wuthnow, The Restructuring of American Religion.

${ }^{19}$ David Morley and Kevin Robins, "Cultural Imperialism and the Mediation of the Otherness," in Akbar S. Ahmed and Cris N. Shore (eds.), The Future of Anthropology: Its Relevance to the Contemporary World (London \& Athlantic Highlands: Athlone, 1995), pp. 228-250; Rosalind I.J. Hackett, "Charismatic/Pantecostal Appropriation of Media 
become an important crossing point spot for dealing with conflict and potentially exploited difference in identity, I would argue in particular that media has become an increasingly important instrument for Muslims to restructure their religious beliefs as well as to reconstruct their religious identity in a more autonomous way.

Despite the rise of the personal autonomy of individuals, the so-called capitalisation of the Islamic publication industry does not necessarily give rise to a reduced attachment of those consumers to their religion. The Islamic print publication facilitates the consumer to better understand their religion. This facilitation significantly benefits many Muslims in Indonesia who are academically less literate or even illiterate in Arabic. This process opens up the for Muslims to accumulate their knowledge about Islamic teachings and to improve their religious understanding and practices, particularly through the publication of translated works, as further discussed below.

In line with such a mediation process by Islamic print publications, the reduction in the prerogatives and authority of religious institutions such as 'ulamä', kyai or ustadr, as suggested above, is unavoidable. In the long history of Indonesian Islam, Muslims sought to learn Islamic teachings by visiting the 'ulamà', kyai or ustad». The reason was that many sources of Islamic teachings were written in Arabic and only those people with excellent skills in Arabic such as 'ulamä', kyai or ustadz would grasp the proper contents of Islamic teachings. In recent developments, however, many Islamic books under the category of kitäb jäwi or kitab kuning in general have been translated into Indonesian. Through these translated works, people can now have easy direct access to those Islamic books or the sources of Islamic ideas without any assistance from the 'ulamā', kyai or ustad\%:

\section{From Rationalisation of Islamic Thinking to Challenging the Authority of Religious Institutions}

The interface between the increasing personal autonomy of the consumers and the reduced prerogatives and authorities of religious institutions such as 'ulamä', kyai or ustadz above has stimulated the

Technologies in Nigeria and Ghana," Journal of Religion in Africa, vol. 28, no. 3 (1998), pp. 258-277. 
rationalisation of Islamic thinking within Indonesian Muslims. Dawam Rahardjo refers to this rationalisation process as "secularisation." 20 He bases his argument on the ideas of another leading Indonesian Muslim scholar, the late Nurcholish Madjid. From Madjid's perspective, secularisation can be discerned as a process of re-understanding worldly values, such as tradition or habit, which have wrongly been perceived as eternal-divine and transcendent. ${ }^{21}$ It differs, in Madjid's view, from so-called secularism which he regards as an ideology that privileges worldly objects to the detriment of eschatological spirit or orientation. Madjid is further convinced that secularisation is useful for Islam in dealing with the ideas of progress in the modern world, but secularism is contradictory to Islam. ${ }^{22}$

The growing size and capitalisation of Islamic print publication in modern Indonesia has contributed to the strengthening of such a rationalisation of Islamic thinking amongst Indonesian Muslims. The call for so-called "secularisation," as indicated above, is required because of the customarily strong personal, unconditional attachment of Muslims to the ideas of their leaders. The vastly increasing development and capitalisation of Islamic print publications raise the possibility of personal criticism by Muslims of the ideas of Islam produced by their leaders and scholars. This personal criticism helps them reduce their earlier unconditional attachment towards the ideas produced by their leaders or scholars on the one hand, and increases their personal independence in an attempt to have a better grasp of Islamic understanding on the other hand. Although it does not necessarily lead to secularisation, through the development of personal independence, the personal criticism allows for greater re-understanding of Islamic teachings which secularisation promotes.

The ideas conveyed through Islamic print publication have further challenged the intellectual authority of local Muslim scholars

${ }^{20}$ M. Dawam Rahardjo, "Sekularisme dan Sekularisasi," Media Indonesia, 11 January 2007.

${ }^{21}$ Nurcholish Madjid, "Keharusan Pembaharuan Pemikiran dan Masalah Integrasi Ummat," in Nurcholish Madjid et al., Pembaharuan Pemikiran Islam (Djakarta: Islamic Research Centre, 1970), p. 5.

${ }^{22}$ Nurcholish Madjid, "Beberapa Catatan Sekitar Masalah Pembaruan Pemikiran dalam Islam," in Islam, Kemodernan dan Keindonesiaan (Bandung: Mizan, 1987), pp. 215-220. 
or leaders such as 'ulamä', kyai or ustadz whom Indonesian Muslims respect and revere. People began to be increasingly aware of the various backgrounds and schools of Islamic legal thinking, from "tolerant", "conservative but non-militant-hardliner", to "fundamentalist-militantjihadist-hardliner" bent of ideology. The fact that the active production and wide consumption of Wihdah's books and Jibadmagz on the market can, for example, be taken as evidence that there is a growing awareness that Indonesia is represented not only by tolerant Islamic ideologies or legal thinking but also by fundamentalist-militant-jihadist-hardliner views of Islam.

Central to this awareness is an understanding that Islamic legal thinking is not singular. In other words, Islamic print publication gave people insight into the diverse background of different schools of Islamic legal thinking, allowing them to compare and contrast the views of such local 'ulamà', kyai or ustadz with ideas conveyed through Islamic print publication. Differences in intellectual inspiration and religious ideology may then arise as a result of this comparison and contrast, as Islamic print publication has provided readers with the opportunity to re-question ideas and interpretations developed by such local 'ulamä', kyai or ustad, who partly subscribe to a single school of Islamic legal thinking.

The increasing level of rationalisation and critical thinking following the greater opportunity to compare and contrast the views or ideas of different Muslim scholars opened up by print publications, leads to the emergence of so-called democratisation of ideas. People begin to enjoy the space available for accessing as wide a view as possible and assessing it through comparative and contrastive analysis and understanding. They reflect their assessment and choose views of Islam which they regard as reasonable, realistic and relevant to their situation of life. The choice of the people may differ from one another, and may result in greater difference not only in consuming Islamic ideas but also in practising them in practical life.

This democratisation of ideas plays a crucial role in establishing and advancing larger democracy in Indonesia. This process in turn requires a strengthened civil society be an important element. The quality of democracy owes much to the eminence of civil society. The more influential civil society, the more likely the quality of a democracy 
increases. The check and balance mechanisms potentially works well partly if civil society and state power, in particular, functions well through taking control of each other.

Civil society can be functional if rationalisation and critical thinking emerge. Print publications contribute to the strengthening of civil society through the process of a democratisation of ideas where different views of thinking are present. Print publication, which assists in the rise of such a rationalisation eventually allows readers to empower themselves through comparative and contrastive analysis and understanding of different views. As such, the significant role of print publications in the process of democratisation can be used as an example to support the argument concerning the interrelationship between media, democracy and the end of authoritarian government in Indonesia. ${ }^{23}$

\section{E. The Politics of Authority and Its Role in Advancing Larger Democracy}

As a further consequence, a so-called "politics of authority" has emerged following the increasing production, capitalisation and marketisation of Islamic print publications in Indonesia. This politics of authority refers to the contested intellectual influence between, for example, local and Arab scholars, pro and anti-formalised shari ah, and between Arab-educated and non-Arab-educated scholars. This contestation of intellectual authority takes place equally both within Islamic book and magazine publications.

The appropriation of scholarship within Islamic print publication, either local or Arab, leads to differences in the way an intellectual authority of Islam is developed. The more conservative and more textual the approach to developing an understanding Islam or Islamic ideology, the higher the exploitation of Arab scholarship in relation to the intellectual authority of Islam. This principle applies to both Islamic book and magazine publications. GIP and Sabili respectively represent Islamic book and magazine publications and/or publishing houses, which strongly

23 See Krishna Sen, "Indonesia: Media and the End of Authoritarian Rule," in Monroe E. Price, Beata Rozumilowicz, and Stefaan G. Verhulst (eds.), Media Reform: Democratizing the Media, Democratizing the State (London; New York: Routledge, 2002), pp. 69-88. 
argue for Arab scholarship to become the main, idealised intellectual authority of Islam. On the contrary, the less conservative and less textual the approach in understanding Islam or in developing an Islamic ideology, the looser the attachment to Arab scholarship. Mizan and Hidayah are respective examples of Islamic book and magazine publications and/ or publishing houses which are not conservative and do not strongly absorb the intellectual authority of Arab scholarship as the main source of Islamic ideas.

Jihäd-oriented Islamic publications, books or magazines, equally consider scholars-cum-activists of the jihäd movement as the strong, main and idealised intellectual authority of Islam. The difference emerges however, in the sources and background of the scholarship. Jibäd-oriented Islamic publishing focuses more on local scholarship as the intellectual authority of Islam. Wihdah is an example of the jihadd-oriented Islamic book strongly adhering to local scholarship as the intellectual authority of Islam. Different from Wihdah, Jihadmagz represents the jïhäd-oriented Islamic magazine publication with Arab scholarship in particular and more global scholarship on jihäd in general as the main, idealised intellectual authority of Islam.

Such a difference in the way intellectual authority is developed gives further rise to the diverse presentation of Islamic ideas and views in print publication. The energetic production of these diverse Islamic ideas and views in print publication on the market, as I noted earlier, adds a contributing factor to this increasingly diverse presentation of the intellectual authority of Islam (views or ideas) in the eyes of consumers. So, people are presented with differing trends of Islamic ideology in print publication. Comparison and contrast, as I indicated earlier, are two useful methods for their attempts in consuming these different concepts of Islamic ideology. These methods contribute to a progression of secularisation in the sense of a rationalisation process that results in the increasing personal autonomy and critical thinking of the consumers. This is not to say however, that the authority of the author will always decline due to a growing secularisation.

Despite the differences in dealing with the politics of authority I noted earlier, all kinds of Islamic print publications, books or magazines, have their own market. This fact sends a significant message that the 
wide consumption of such diverse publications by an extensive range of Muslims makes stronger the challenge for the intellectual authority of such local Muslim scholars discussed above. The active publication of fundamentalist-militant-jihadist-hardliner views and ideas, both in Wihdah's book and Jihadmagr, for example, challenges the tolerant intellectual authority of such local Muslim scholars. The marketability of Wihdah's book and Jihadmagz further shows the greater challenge posed by fundamentalist-militant-jihadist-hardliner ideological thinking towards the tolerant views and intellectual authority in Indonesia. The response by the tolerant Muslim thinkers to this challenge contributes to the dynamism of Islamic thinking in Indonesia.

This study further finds that the increasing public manifestation of Islamic print publications has allowed consumers to reconstruct their understanding of Islamic teachings and to remake their personal religious identity in the face of the prerogatives and authority of religious institutions such as 'ulamā', kyai or ustad». This implies that Islamic print publications not only accommodate the market but also perpetuate and create market forces of its own. The market is created in particular through the wide extension of publications towards readers other than its own captive audience. This kind of audience extension owes much to the opportunity for reflection provided by print publications concentration on Islamic ideas in the search for obtaining a deep understanding of both the emotional and doctrinal aspects of Islamic ideas or views, as well as providing a chance for comparison and contrast of different Islamic ideas.

An exception arises if each segment of the market has a captive audience. In this condition, such a reconstruction of Islamic understanding and personal religious identity depends on extent that readers escape from captivity and move beyond such a niche. For example, the captive audience of Jihadmagz tend to restrengthen their fundamentalist-militant-jihadist-hardliner Islamic understanding more than to reconstruct it. Likewise, they tend to reaffirm or reattach their personal identity to their religious mentors in jihäd activities more than to remake it. Such a similar exception also applies to the captive audience of other kinds of Islamic print publication within different ideologies.

The rise of such a level of autonomy and independence in religious understanding and practise among Muslim consumers is also associated 
with the nature of auto-didactic discourse. As a method of learning, auto-didacticism allows Muslims to discover knowledge of Islam through self-design and self-direction within the teaching-learning process, relying more on self-capability and the availability of sources for Islamic learning. ${ }^{24}$ It results from the mass production, marketisation and capitalisation of different ideas and publication media. Different ideas and trends of thinking presented through print publication become sources for Islamic learning. This nature of auto-didacticism contributes to the nurturing of autonomy and independence in Muslims' understanding and practising of Islamic teachings.

\section{F. Conclusion}

In order for democracy to flourish it has to be perceived, as David Held and John Keane argue, as "a double-sided phenomenon: concerned, on the one hand, with the re-form of state power and, on the other hand, with the restructuring of civil society." 25 The more autonomous the civil society, the stronger the democracy practices. In other words, the more independent the civil society from the state, the better the quality of democracy practices. Power relationship between state and civil society becomes, therefore, a key issue within the democratisation process. However, from the perspective of David Held, "the principle of autonomy can only be enacted by recognizing the indispensability of a process of 'double democratization': the independent transformation of both state and civil society." 26

The balanced power relationship between the state and civil society is necessary when attempting to achieve the greater quality of democracy at both the social structural level as well as political level. Such a notion of "double democratisation" allows, or even requires, the principle of balance within the social structure to flourish, that is between the elite and the lower people. In the Indonesian context, where Muslims are the vast majority of population, this principle of balance deserves to work with regard to the relationship between the religious elite and the lower levels

${ }^{24}$ For more details about autodidacticism, see Joan Solomon (ed.), The Passion to Learn: An Inquiry into Autodidactism (London: RoutledgeFalmer, 2003).

${ }^{25}$ David Held and John Keane, "Socialism and the Limits of State Action," in James Curran (ed.), The Future of the Left (Cambridge: Polity Press, 1984), pp. 170-81.

${ }^{26}$ Held, Models of Democracy, p. 283. 
within communities as well as among the same level of communities.

To come to its best practices, democracy must be nurtured from the bottom up, with a well-developed set of values, such as rule of law, political tolerance, freedom of expression, and accountability. With its capacity in maintaining the transportability of the message over space and its durability over time, as suggested above, print media publications serve as an example of the crystallisation of such a set of values within the community. The nurturing of democracy in Indonesia then cannot undermine the role of Muslim activism, particularly in producing and consuming their ideas through print publication.

Moreover, the production of Islamic ideas through print media contributes not only to advancing larger democracy but also to sustaining it. The challenge of making democracy sustainable comes when the struggle for power and meaning-making between those who govern, particularly in religious senses, and those who are being governed cannot be negotiated carefully and thoroughly. Print media paves the way for people from any sociological background to produce their own ideas, and these ideas are consumed by others. A larger amount of people are now provided with different kinds of ideas developed through print (and also non-print) publications.

Yet, a task remains for Muslims from the so-called mainstream ideological background. The production of Islamic ideas promoting tolerance and pluralism are now under attack from the publication of non-tolerant and non-pluralist views of Islam. The market has recently been flooded by such Islamic publications. Furthermore, recent experiences from several book exhibitions show that the number of print publication of non-tolerant views of Islam has increased and attracted consumers. Based on my observations of two Jakarta Islamic Book Fairs in 2008 and 2010 and Bandung's 2008 Islamic Book Fair, stalls selling Islamic publications produced by publishers from such an ideological background, such as Ar Rahmah Media Network, al-Jazeera, and alMuqawamah attracted wider consumers. People flocked to those stalls and bought their print publications.

In line with the increase in personal autonomy and rationalisation of Islam thinking among individuals within Muslims communities and the reduction in the intellectual authority of religious institutions, the 
production of print publications promoting tolerant and pluralist views of Islam needs to be increased in such a way that people have options other than books and magazines exploiting a non-tolerant and non-pluralist ideology of Islam. A check and balance process will then emerge where people can compare and contrast different views of Islam developed through print media. This mechanism will assist in the nurturing of democracy from below that can be undertaken by sustaining a core set of values from which the democracy is founded. 
Advancing Larger Democracy in Indonesia through Islamic Print Media

\section{BIBLIOGRAPHY}

Barker, Eileen, "Crossing Boundary: New Challenges to Religious Authority and Control as a Consequence of Access to the Internet," in Morten T. Højsgaard \& Margit Warburg, Religion and Cyberspace, New York: Routledge, 2005.

Bourchier, David and John Legge (eds.), Democracy in Indonesia, 1950s and 1990s, Clayton, Victoria: Centre of Southeast Asian Studies, Monash University, 1994.

Fealy, Greg, "Consuming Islam: Commodified Religion and Aspirational Pietism in Contemporary Indonesia," in Greg Fealy and Sally White (eds.), Expressing Islam: Religious Life and Politics in Indonesia, Singapore: Institute of Southeast Asian Studies, 2008.

Flew, Terry, New Media: An Introduction, Melbourne: London: Oxford University Press, 2005.

Hackett, Rosalind I.J., "Charismatic/Pantecostal Appropriation of Media Technologies in Nigeria and Ghana," Journal of Religion in Africa, vol. 28, no. 3, 1998.

Hadiwinata, Bob S. and Christoph Schuck (eds.), Democracy in Indonesia: The Challenge of Consolidation, Baden-Baden: Nomos, 2007.

Hasan, Noorhaidi, Laskar Jihad: Islam, Militancy, and the Quest for Identity in Post-New Order Indonesia, Ithaca: Southeast Asia Program, Cornell University, 2006.

Held, David, Models of Democracy, Cambridge: Polity Press, 1987.

---- and John Keane, "Socialism and the Limits of State Action," in James Curran (ed.), The Future of the Left, Cambridge: Polity Press, 1984.

Hoover, Stewart M., "Religion, Media and Identity: Theory and Method in Audience Research on Religion and Media," in Jolyon Mitchell and Sophia Marriage (eds.), Mediating Religion: Conversations in Media, Religion and Culture, London, New York: T \& T Clark, 2003.

Hwang, Julie Chernov, "Does Participation Matter? Effective Authoritarianism in New Order Indonesia," in Peaceful Islamist Mobilization in the Muslim World: What Went Right, New York: Palgrave 
Macmillan, 2009.

Louw, P. Eric, The Media and Cultural Production, London, Thousand Oaks, New Delhi: SAGE Publications, 2001.

Madjid, Nurcholish, "Beberapa Catatan Sekitar Masalah Pembaruan Pemikiran dalam Islam," in Islam, Kemodernan dan Keindonesiaan, Bandung: Mizan, 1987.

----, "Keharusan Pembaharuan Pemikiran dan Masalah Integrasi Ummat," in Nurcholish Madjid et al., Pembaharuan Pemikiran Islam, Djakarta: Islamic Research Centre, 1970.

Mann, Richard, Fight for Democracy in Indonesia, Canada: Gateway, 1999.

McLuhan, Marshall, The Medium is the Massage: An Inventory of Effects, New York: Random House, 1967.

Meisbuger, Tim, Democracy in Indonesia: A Survey of the Indonesian Electorate in 2003, Jakarta: The Asia Foundation, 2003.

Morley, David and Kevin Robins, "Cultural Imperialism and the Mediation of the Otherness," in Akbar S. Ahmed and Cris N. Shore (eds.), The Future of Anthropology: Its Relevance to the Contemporary World, London \& Athlantic Highlands: Athlone, 1995.

Rahardjo, M. Dawam, "Sekularisme dan Sekularisasi," Media Indonesia, 11 January 2007.

Roof, Wade Clark, Spiritual Marketplace: Baby Boomers and the Remaking of American Religion, Princeton, New Jersey: Princeton University Press, 1999.

Salman, M.U., "Saatnya Media Islam Tampil," Sabili, no. 10, year XII, 3 December 2004.

Sen, See Krishna, "Indonesia: Media and the End of Authoritarian Rule," in Monroe E. Price, Beata Rozumilowicz, and Stefaan G. Verhulst (eds.), Media Reform: Democratizing the Media, Democratizing the State, London; New York: Routledge, 2002.

Solomon, Joan (ed.), The Passion to Learn: An Inquiry into Autodidactism, London: RoutledgeFalmer, 2003.

Wuthnow, Robert, The Restructuring of American Religion: Society and Faith since World War II, Princeton: Princeton University Press, 1988. 
Advancing Larger Democracy in Indonesia through Islamic Print Media

\section{Interviews}

Jibriel, Interview, Bintaro, Tangerang, Banten, 25 April 2008.

Ridwan, the editor-in-chief of Hidayah, Interview, Depok, 27 March 2008. 
Akh. Muzakki 